\title{
Chronic illnesses and polypharmacy in elderly patients: A hospital-based study in Northern Sri Lanka
}

${ }^{1}$ Thiyahiny $S$ N, ${ }^{1}$ Kumanan $T$, ${ }^{1}$ Surenthirakumaran $R$

${ }^{I}$ Faculty of Medicine, University of Jaffna

\section{Abstract}

Population aging and multiple pathology among older people have increased medicines use in elderly. Aim of this study was to evaluate chronic illnesses and polypharmacy and to determine factors associated with polypharmacy among hospitalized elderly at Teaching Hospital-Jaffna.

This was a cross sectional, descriptive study. Elderly and polypharmacy were defined as $\geq 65$ years and concomitant use of $\geq 6$ medications for $\geq 1$ month respectively. Data were collected from bedhead-tickets of 288 elderly patients using data extraction sheet. Chi-squared and paired t-test were performed to determine the level of significance and unadjusted odd ratios were calculated to determine the association between polypharmacy and common chronic illnesses. A $p$ value $<0.05$ was set as statistically significance.

Mean age was $72(\mathrm{SD} \pm 6.2)$ and majority were males (53.5\%). Relatively higher proportion, $58.7 \%(n=169)$ of patients had polypharmacy. Seven chronic illnesses were prevalent in $>10 \%$ of the patients. Lipid-modifying (80.9\%) and antithombotic agents (76.4\%) were the top two subgroups prescribed to elderly. Polypharmacy was substantially increased with increasing number of chronic illnesses $(p<0.05)$. Significant association $(p<0.05)$ was found between polypharmacy and coronary heart disease, anaemia, heart failure, asthma and diabetes mellitus. Significantly greater number of medications were prescribed on discharge compared to admission $(p<0.05)$.
This study concluded that polypharmacy was common among hospitalized elderly and increases with hospitalization. There was increased tendency to prescribe antithrombotic and lipid-modifying agents. These findings indicate the need for medication reconciliation and review in elderly patient. Further studies targeting wider population are needed to determine the appropriateness of polypharmacy in elderly.

\section{Key words}

elderly, chronic illness, polypharmacy

\section{Introduction}

Sri Lanka is one of the fastest aging countries (1). According to the 2012 census, $7.84 \%$ of the population of Sri Lanka is 65 years and above (2). One of the major challenges of population aging is chronic non-communicable diseases which commonly affect adults and elderly. Rapidly growing aging population will increase the demands of health care system and there is a need to address the health issues of older people. Because of multiple co-morbidities, elderly suffer from more symptoms and illnesses than the young which contribute to polypharmacy $(3,4)$. Increasing tendency to use more than one medication for optimal treatment of a single condition causes further increase in the medicines use in elderly (5). Polypharmacy is the use of multiple medications and is one of the major and common health-related issues of elderly patients $(6,7)$. The definition of 
polypharmacy varies according to the population and study setting (8). Though there is no universally accepted formal definition for polypharmacy, it generally refers to the simultaneous use of multiple medications (more than 4-6 medications) $(9,10$, 11).

Although elderly patients have the greatest potential to benefit from multiple drug therapy, they are more susceptible to the adverse consequences of polypharmacy than younger people because of age-related physiological changes, decline in organ functions and various pathological changes which affect the pharmacokinetics and pharmacodynamics of drugs $(12,13,14)$.

Like many developing countries geriatric health needs are emerging problem in Sri Lanka. This study was carried out with the aim of evaluating the common chronic illnesses and polypharmacy and to determine the factors associated with polypharmacy among elderly patients treated in the medical wards of Teaching Hospital-Jaffna.

\section{Methods}

This was a hospital-based, cross sectional, descriptive study conducted among elderly patients ( $\geq 65$ years) admitted to medical wards of Teaching Hospital-Jaffna which is the largest tertiary care hospital in the Northern Province of Sri Lanka. Ethical approval was obtained from the Ethics Review Committee of Faculty of Medicine, University of Jaffna and administrative approvals were obtained from relevant authorities.

Eligible patients were identified from admission registries of medical wards and recruited consecutively. Data were collected from the bedhead tickets of 288 elderly patients admitted to the medical wards over a period of 3 months using a data extraction sheet. Patients who were transferred to other units or institutes and those died during the hospital stay were excluded. The collected information include age, sex, chronic illnesses, medications on admission and discharge.

\section{Case definitions}

In this study polypharmacy was defined as simultaneous use of six or more medications for the duration of one month or more. Chronic illness that were prevalent in $10 \%$ or more of the study population and medications prescribed to $10 \%$ or more of the study population were considered as common chronic illnesses and commonly prescribed medications respectively. Medications are classified at level 3 of the Anatomical Therapeutic Chemical (ATC) classification (15).

\section{Data analysis}

Analysis of medications was done with medications prescribed on discharge except the analysis between admission and discharge where medications prescribed on admission and discharge were taken for comparison. Descriptive statistics such as frequencies, percentage mean, median and range were used to present the results. Chi-square test was used to determine the association between polypharmacy and age, sex and number of illness. Paired t-test was used to determine the level of significance between the number of medications prescribed on admission and on discharge and unadjusted odd ratio (OR) was used to identify the common chronic illnesses that were associated with polypharmacy. Data were analyzed using 95\% confidence interval (CI) and a $p$ value less the 0.05 was considered significant.

\section{Results}

Data from 288 elderly patients were anaylsed. The mean age of the study population was 72 years ( $\mathrm{SD} \pm 6.2$ ), ranging from 65 to 90 years and males were slightly higher (53.5\%) than females (46.5\%). Table 1 shows the distribution of polypharmacy 
among different age groups and sex. Majority of the patients (58.7\%) had polypharmacy. There was no significant association between polypharmacy and age group or sex.

Table 1. Distribution of polypharmacy among different age groups and sex

\begin{tabular}{|l|l|l|}
\hline $\begin{array}{l}\text { Demographic fac- } \\
\text { tor }\end{array}$ & $\begin{array}{l}\text { Patients not } \\
\text { ex o s e t o } \\
\text { polypharmacy } \\
\text { n (\%) }\end{array}$ & $\begin{array}{l}\text { Patients exposed } \\
\text { to polypharmacy } \\
\text { n (\%) }\end{array}$ \\
\hline Age (years) & \multicolumn{2}{|l|}{} \\
\hline $65-69$ & $43(37.4)$ & $72(62.6)$ \\
\hline $70-74$ & $33(41.2)$ & $47(58.8)$ \\
\hline $75-79$ & $24(44.4)$ & $30(55.6)$ \\
\hline $80-84$ & $11(42.3)$ & $15(57.7)$ \\
\hline$\geq 85$ & $08(61.5)$ & $05(38.5)$ \\
\hline Sex & $65(42.2)$ & $89(57.8)$ \\
\hline Male & $54(40.3)$ & $80(59.7)$ \\
\hline Female & $\mathbf{1 1 9 ( 4 1 . 3 )}$ & $\mathbf{1 6 9 ( 5 8 . 7 )}$ \\
\hline Total & & \multicolumn{2}{|l}{} \\
\hline
\end{tabular}

Among the 48 chronic illnesses that were prevalent in 288 elderly patients, 7 occurred in more than $10 \%$ of patients. Hypertension was the most prevalent chronic illness, seen in 53.1\% patients followed by coronary heart disease $(48.6 \%)$ diabetes mellitus (41.7\%), asthma (22.6\%), cerebrovascular disease (12.8\%), anaemia (11.8\%) and heart failure (11.5\%). Peptic ulcer disease, chronic kidney diseases, dyslipidaemia, valvular heart illness, hypothyroidism, osteoarthritis and chronic obstructive pulmonary disease were observed in more than $5 \%$ of the patients. On average, all the patients with common chronic illnesses had three or more chronic illnesses and prescribed with more than 5 medications (ranging from 5.4 to 7.4 ).

Table 2 shows the distribution of common chronic illnesses among different age groups and sex and Table 3 shows the distribution of comorbidities among common chronic illnesses. Hypertension was the predominant chronic illness in all age groups except the age group 70-74years. The most

Table 2. Distribution of common chronic illnesses among different age groups and sex

\begin{tabular}{|c|c|c|c|c|c|c|c|}
\hline \multirow[b]{2}{*}{$\begin{array}{l}\text { Demographic } \\
\text { factors }\end{array}$} & \multicolumn{7}{|c|}{ Common chronic illnesses } \\
\hline & $\begin{array}{c}\text { Hyperten- } \\
\text { sion } \\
\text { n (\%) }\end{array}$ & $\begin{array}{c}\text { Coronary } \\
\text { heart disease } \\
\text { n (\%) }\end{array}$ & $\begin{array}{l}\text { Diabetes } \\
\text { mellitus } \\
\text { n (\%) }\end{array}$ & $\begin{array}{c}\text { Asthma n } \\
(\%)\end{array}$ & $\begin{array}{l}\text { Cerebro- } \\
\text { vascular } \\
\text { disease } n \\
(\%)\end{array}$ & $\begin{array}{l}\text { Anaemia } \\
\text { n (\%) }\end{array}$ & $\begin{array}{l}\text { Heart } \\
\text { failure } \\
\text { n (\%) }\end{array}$ \\
\hline \multicolumn{8}{|l|}{ Age (years) n (\%) } \\
\hline $65-69$ & $60(52.2)$ & $48(41.7)$ & $52(45.2)$ & $26(22.6)$ & $10(8.7)$ & $15(13.0)$ & $10(8.7)$ \\
\hline $70-74$ & $43(53.8)$ & $45(56.3)$ & $31(38.8)$ & $17(21.3)$ & $10(12.5)$ & $11(13.8)$ & $9(11.3)$ \\
\hline $75-79$ & $31(57.4)$ & $29(53.7)$ & $23(42.6)$ & $15(27.8)$ & $10(18.5)$ & $3(5.6)$ & $7(13.0)$ \\
\hline $80-84$ & $13(50.0)$ & $12(46.2)$ & $11(42.3)$ & $5(19.2)$ & $6(23.1)$ & $5(19.2)$ & $7(26.9)$ \\
\hline$\geq 85$ & $6(46.2)$ & $6(46.2)$ & $3(23.1)$ & $2(15.4)$ & $1(7.7)$ & $0(0.0)$ & $0(0.0)$ \\
\hline \multicolumn{8}{|l|}{$\operatorname{Sex} n(\%)$} \\
\hline Male & $69(44.8)$ & $77(50.0)$ & $63(40.9)$ & $36(23.4)$ & $17(11.0)$ & $14(9.1)$ & $21(13.6)$ \\
\hline Female & $84(62.7)$ & $63(47.0)$ & $57(42.5)$ & $29(21.6)$ & $20(14.9)$ & $20(14.9)$ & $12(9.0)$ \\
\hline
\end{tabular}


Table 3. Distribution of comorbidities among common chronic illnesses

\begin{tabular}{|c|c|c|c|c|c|c|c|c|}
\hline \multirow{2}{*}{$\begin{array}{l}\text { Common } \\
\text { chronic illness }\end{array}$} & \multicolumn{8}{|c|}{ Comorbidities } \\
\hline & $\begin{array}{l}\text { Hyperten- } \\
\text { sion } \\
\text { n (\%) }\end{array}$ & $\begin{array}{l}\text { Coronary } \\
\text { heart } \\
\text { disease n } \\
(\%)\end{array}$ & $\begin{array}{l}\text { Diabetes } \\
\text { mellitus } \\
\text { n }(\%)\end{array}$ & $\begin{array}{l}\text { Asthma } \\
\text { n (\%) }\end{array}$ & $\begin{array}{l}\text { Cerebro- } \\
\text { vascular } \\
\text { disease } \\
n(\%)\end{array}$ & $\begin{array}{l}\text { Anaemia } \\
\text { n (\%) }\end{array}$ & $\begin{array}{l}\text { Heart } \\
\text { failure } \\
\text { n (\%) }\end{array}$ & $\begin{array}{l}\text { Others } \\
\text { n (\%) }\end{array}$ \\
\hline Hypertension & $153(100.0)$ & $72(47.1)$ & $62(40.5)$ & $32(20.9)$ & $27(17.6)$ & $17(11.1)$ & $15(9.8)$ & $65(42.5)$ \\
\hline $\begin{array}{l}\text { Coronary heart } \\
\text { disease }\end{array}$ & $70(50.0)$ & $140(100.0)$ & $51(36.4)$ & $33(23.6)$ & $15(10.7)$ & $13(9.3)$ & $23(16.4)$ & $55(39.3)$ \\
\hline $\begin{array}{l}\text { Diabetes mel- } \\
\text { litus }\end{array}$ & $49(40.8)$ & $61(50.8)$ & $120(100.0)$ & $19(15.8)$ & $11(9.2)$ & $17(14.2)$ & $13(10.8)$ & $47(39.2)$ \\
\hline Asthma & $31(47.7)$ & $32(49.2)$ & $19(29.2)$ & $65(100.0)$ & $1(1.5)$ & $7(10.8)$ & $7(10.8)$ & $27(41.5)$ \\
\hline $\begin{array}{l}\text { Cerebrovascu- } \\
\text { lar disease }\end{array}$ & $25(67.6)$ & $17(45.9)$ & $11(29.7)$ & $1(2.7)$ & $37(100.0)$ & $3(8.1)$ & $4(10.8)$ & $14(37.8)$ \\
\hline Anaemia & $17(50.0)$ & $14(41.2)$ & $17(50.0)$ & $3(8.8)$ & $3(8.8)$ & $34(100.0)$ & $6(17.6)$ & $19(55.9)$ \\
\hline Heart failure & $15(45.5)$ & $22(66.7)$ & $13(39.4)$ & $7(21.2)$ & $3(9.1)$ & $6(18.2)$ & $33(100.0)$ & $15(45.5)$ \\
\hline
\end{tabular}

common chronic illness in males was coronary heart disease while hypertension was the most common chronic illness among females. The top three commodities were hypertension $(40.8 \%$ $67.6 \%)$, coronary heart disease $(41.2-66.7 \%)$ and diabetes mellitus $(29.2-50 \%)$.

Out of 57 pharmacological subgroups (level 3 ATC classification) of medications prescribed for the elderly, 20 subgroups were prescribed to more than $10 \%$ of the patients (Table 4 ).

Table 4. Commonly prescribed medications for elderly

\begin{tabular}{|l|l|l|l|}
\hline \multirow{2}{*}{ ATC } & \multirow{2}{*}{$\begin{array}{l}|l| \\
\text { code }\end{array}$} & Description & \multicolumn{2}{|l|}{$\begin{array}{l}\text { exposed to the } \\
\text { medications }\end{array}$} \\
\cline { 3 - 4 } & & $\mathbf{n}$ & $\%$ \\
\hline C10A & $\begin{array}{l}\text { Lipid-modifying agents, } \\
\text { plain }\end{array}$ & 233 & 80.9 \\
\hline B01A & Antithrombotic agents & 220 & 76.4 \\
\hline C09A & $\begin{array}{l}\text { Angiotensin converting en- } \\
\text { zyme inhibitors, plain }\end{array}$ & 98 & 34.0 \\
\hline A10B & $\begin{array}{l}\text { Blood glucose lowering } \\
\text { drugs, excluding insulins }\end{array}$ & 96 & 33.3 \\
\hline
\end{tabular}

\begin{tabular}{|c|c|c|c|}
\hline C01D & $\begin{array}{l}\text { Vasodilators used in cardiac } \\
\text { diseases }\end{array}$ & 86 & 29.9 \\
\hline $\mathrm{C} 03 \mathrm{C}$ & High-ceiling diuretics & 81 & 28.1 \\
\hline $\mathrm{C} 09 \mathrm{C}$ & $\begin{array}{l}\text { Angiotensin ii receptor block- } \\
\text { ers, plain }\end{array}$ & 79 & 27.4 \\
\hline A02B & $\begin{array}{l}\text { Drugs for peptic ulcer and } \\
\text { gastro-oesophageal reflux } \\
\text { disease }\end{array}$ & 70 & 24.3 \\
\hline R03A & Adrenergics, inhalants & 70 & 24.3 \\
\hline R03B & $\begin{array}{l}\text { Other drugs for obstructive } \\
\text { airway diseases, inhalants }\end{array}$ & 62 & 21.5 \\
\hline C03D & Potassium-sparing agents & 56 & 19.4 \\
\hline C07A & Beta blocking agents & 51 & 17.7 \\
\hline N02B & $\begin{array}{l}\text { Other analgesics and anti- } \\
\text { pyretics }\end{array}$ & 52 & 18.1 \\
\hline $\mathrm{C} 08 \mathrm{C}$ & $\begin{array}{l}\text { Selective calcium channel } \\
\text { blockers with mainly vascu- } \\
\text { lar effects }\end{array}$ & 50 & 17.4 \\
\hline A11E & $\begin{array}{l}\text { Vitamin B-complex, includ- } \\
\text { ing combinations }\end{array}$ & 48 & 16.7 \\
\hline C08D & $\begin{array}{l}\text { Selective calcium channel } \\
\text { blockers with direct cardi- } \\
\text { ac effects }\end{array}$ & 42 & 14.58 \\
\hline $\mathrm{C} 03 \mathrm{~A}$ & $\begin{array}{l}\text { Low-ceiling diuretics, thi- } \\
\text { azides }\end{array}$ & 38 & 13.2 \\
\hline A10A & Insulins and analogues & 35 & 12.2 \\
\hline B03A & Iron preparations & 32 & 11.1 \\
\hline B03B & Vitamin B12 and folic acid & 32 & 11.1 \\
\hline
\end{tabular}

Jaffna Medical Journal 
The top two subgroups of medications were lipidmodifying $(80.9 \%)$ and antithrombotic agents (76.4\%). Lipid-modifying agents were prescribed to 233 patients and atorvastatin was prescribed to all $(n=233)$ patients. Only a few $(n=3)$ were on more than one lipid-modifying agent. Total of 300 antithrombotic agents were prescribed to 220 patients. Among the patients prescribed with antithrombotic agents prescribed one third $(n=71)$ of patients received more than one antithrombotic agent. Aspirin, clopidogrel, dipyridamole and warfarin were the antithrombotic agents prescribed in this study and were prescribed to $56 \%(n=163)$, $37.9 \%(n=103), 5.9 \%(n=17)$ and $3.8 \%(n=11)$ of patients respectively.

Table 5 shows the relationship between number of chronic illnesses and number of medications prescribed. On average six medications were prescribedperpatient, ranging from 1 to 12 . Therewas statistically significant association between number of chronic illnesses and number of medications $(\mathrm{p}<0.001)$.

Table 5. Number of chronic illness and number of medications

\begin{tabular}{|l|l|l|l|l|}
\hline $\begin{array}{l}\text { Num- } \\
\text { ber of } \\
\text { chronic } \\
\text { illnesses }\end{array}$ & $\begin{array}{l}\text { Patients } \\
\text { not } \\
\text { exposed } \\
\text { to poly- } \\
\text { pharma- } \\
\text { cy } \\
\text { n (\%) }\end{array}$ & $\begin{array}{l}\text { Patients } \\
\text { exposed } \\
\text { to poly- } \\
\text { pharma- } \\
\text { cy } \\
\text { n (\%) }\end{array}$ & Mean (SD) & Range \\
\hline $\mathbf{2}$ & $41(87.2)$ & $06(12.8)$ & $3.5( \pm 1.76)$ & $1-7$ \\
\hline $\mathbf{3}$ & $43(50.0)$ & $43(50.0)$ & $5.4( \pm 1.88)$ & $1-11$ \\
\hline $\mathbf{4}$ & $23(27.4)$ & $61(72.6)$ & $6.8( \pm 2.07)$ & $3-12$ \\
\hline$\geq \mathbf{5}$ & $10(21.7)$ & $36(78.3)$ & $6.8( \pm 1.79)$ & $4-12$ \\
\hline Total & $\mathbf{1 1 9}(8.0)$ & $23(92.0)$ & $8.6( \pm 2.21)$ & $5-12$ \\
\hline
\end{tabular}

$* p<0.05$
Distribution of polypharmacy among common chronic illnesses was shown in Table 6.

Table 6. Distribution of polypharmacy among common chronic illnesses

\begin{tabular}{|c|c|c|c|}
\hline $\begin{array}{l}\text { Chronic } \\
\text { illness }\end{array}$ & $\begin{array}{l}\text { Patients not } \\
\text { exposed to } \\
\text { polyphar- } \\
\text { macy } \\
\text { n (\%) }\end{array}$ & $\begin{array}{l}\text { Patients } \\
\text { exposed to } \\
\text { polyphar- } \\
\text { macy } \\
\text { n (\%) }\end{array}$ & $\begin{array}{l}\text { Odds ratio } \\
(95 \% \mathrm{CI})\end{array}$ \\
\hline Hypertension & $58(37.9)$ & $95(62.1)$ & $\begin{array}{r}1.35(0.84 \\
\text { to } 2.16)\end{array}$ \\
\hline $\begin{array}{l}\text { Coronary } \\
\text { heart disease }\end{array}$ & $42(30)$ & $98(70)$ & $\begin{array}{l}2.53(1.52 \\
\text { to } 4.23)^{*}\end{array}$ \\
\hline $\begin{array}{l}\text { Diabetes } \\
\text { mellitus }\end{array}$ & $39(32.5)$ & $81(67.5)$ & $\begin{array}{r}1.89(1.13 \\
\text { to } 3.17)^{*}\end{array}$ \\
\hline Asthma & $18(27.7)$ & $47(72.3)$ & $\begin{array}{r}2.16(1.14 \\
\text { to } 4.20)^{*}\end{array}$ \\
\hline $\begin{array}{l}\text { Cerebrovas- } \\
\text { cular disease }\end{array}$ & $19(51.4)$ & $18(48.6)$ & $\begin{array}{l}0.75(0.35 \\
\text { to } 1.58)\end{array}$ \\
\hline Anaemia & $8(23.5)$ & $26(76.5)$ & $\begin{array}{l}2.52(1.05 \\
\text { to } 6.68)^{*}\end{array}$ \\
\hline Heart failure & $8(24.2)$ & $25(75.8)$ & $\begin{array}{l}2.41(1.00 \text { to } \\
6.41)^{*}\end{array}$ \\
\hline
\end{tabular}

Using less than six medication as referent, polypharmacy was associated with all common chronic illnesses except cerebrovascular disease (OR 0.75; 95\% CI: 0.35 - 1.58). Likelihood of having polypharmacy in descending order was coronary heart disease (OR 2.53; 95\% CI: 1.52 4.23), anaemia (OR 2.52; 95\% CI: $1.05-6.68$ ) and heart failure (OR 2.41; 95\% CI: 1.00-6.41), asthma (OR 2.16; 95\% CI: 1.14 - 4.20), diabetes mellitus (OR 1.89; 95\% CI: $1.13-3.17$ ) and hypertension (OR 1.35; $0.84-2.16$ ). Statistically significant association was found between polypharmacy and coronary heart diseases, diabetes mellitus, asthma, anaemia and heart failure $(p<0.05)$. 
Mean number of medications prescribed on admission and discharge were 4.3 (range $0-14$ ) and 6.0 (range 1-12) respectively (Table 7).

Table 7. Number of medications prescribed on admission and on discharge

\begin{tabular}{|l|l|l|l|l|}
\hline $\begin{array}{l}\text { Encoun- } \\
\text { ter }\end{array}$ & $\begin{array}{l}\text { Patients } \\
\text { not ex- } \\
\text { posed to } \\
\text { polyphar- } \\
\text { macy } \\
\text { n (\%) }\end{array}$ & $\begin{array}{l}\text { Patients } \\
\text { exposed } \\
\text { to poly- } \\
\text { pharma- } \\
\text { cy } \\
\text { n (\%) }\end{array}$ & $\begin{array}{l}\text { Mean } \\
\text { (SD) } *\end{array}$ & Range \\
\hline $\begin{array}{l}\text { Admis- } \\
\text { sion }\end{array}$ & $169(58.7)$ & $119(41.3)$ & 4.3 & $0-14$ \\
\hline Discharge & $119(41.3)$ & $169(58.7)$ & 6.0 & $1-12$ \\
$( \pm 3.36)$ & & \\
\hline
\end{tabular}

$* t=10.25 ; p<0.05$

Polypharmacy was noticed in $41.3 \%$ patients on admission and in $58.7 \%$ on discharge. On average about 2 medications were added after each admission. When compared to admission, significantly greater number of medications were prescribed on discharge $(\mathrm{p}<0.001)$.

\section{Discussion}

The three main findings of this cross-sectional study among hospitalized elderly in medical wards of Teaching Hospital-Jaffna are; 1) polypharmacy was common among hospitalized elderly and increases with hospitalization; 2) significant association between polypharmacy and number and types of chronic illnesses was observed; 3) there was a tendency to prescribe antithrombotic and lipid-modifying agents.

Prevalence of polypharmacy varies widely because of the differences in defining polypharmacy and criteria for patient selection. A review on multiple diseases and polypharmacy in the elderly reported that the prevalence of polypharmacy among hospitalized elderly varied from $20 \%$ to $60 \%$. (16) In the present study prevalence of polypharmacy
(59\%) was at the higher end of the above range. Mean number of medications prescribed for elderly in the present study was 6.03 and similar finding was reported in a study conducted among elderly in an outpatient setting in United States (11). A higher mean number of medications (8.7) was reported in a study conducted among community-dwelling elderly in Australia (17). Findings of this study showed that significantly greater number of medications were prescribed on discharge, compared to admission (mean number of medications on admission vs on discharge $=4.4$ vs 6.03). Similar findings were reported in studies conducted among hospitalized elderly in Australia and Italy $(18,19)$.

Unlike most of the other studies, the present study did not show significant association between polypharmacy and age or sex $(11,17,20)$. Two studies that were conducted in primary care elderly patients in Germany and hospitalized elderly patients in Italy support the above findings of this study $(19,21)$.

The present study found that there was significant association between number and types (coronary heart disease, diabetes mellitus, asthma, anaemia and heart failure) of chronic illnesses and previous studies that investigated the factors associated with polypharmacy supported these findings (20-22). It is not surprising that number of chronic illnesses is associated with polypharmacy as patients with multiple illnesses require multiple medications. Since optimal treatment of chronic illnesses that are associated polypharmacy in this study require multiple medications, it is expected that patients with these chronic illnesses may exceed the threshold for polypharmacy. However, it is difficult to decide the appropriateness of polypharmacy based on number of medications alone. An interesting finding of this study was that a lower risk of exposure to polypharcmy in cerebrovascular diseases. Discontinuation of antithrombotic agents 
in patients with haemorrhagic stroke could be the reason for this observation.

Cardiovascular diseases were the predominant chronic illnesses in this study, which was followed by diabetes mellitus, asthma and anaemia. These findings were similar to the distribution of noncommunicable diseases in Sri Lanka except neoplasm $(23,24)$. Most of the cancer patients are treated in the specialized cancer units which could explain the lower prevalence (1\%) of neoplasm in this study population. Results of studies conducted among elderly in other countries also showed that cardiovascular diseases were the most common chronic condition in elderly $(6,10,17,25)$.

A tendency to prescribe antithrombotic and lipidmodifying agents was observed in the present study. Proportion of elderly patients prescribed with lipidmodifying (81\%) and antithrombotic (76\%) agents in this study was higher when compared to other studies (37-64\% and 50-70\% respectively) (11, 25 ). In this study many patients ( $25 \%$ of the study population) received more than one antithrombotic agent. Among this study population $82 \%$ had cardiovascular disease (one or more) and this could be the reason for higher prescription rates for lipidmodifying and antithrombotic agents. However, further evaluation in this regard is needed to comment on the appropriateness of this prescribing tendency.

\section{Limitations}

This study was conducted in hospitalized elderly. Findings of this study may not reflect the prevalence of chronic illnesses and polypharmacy among elderly in the community. Further, only elderly patients admitted to medical wards were included in this study which may not represent all hospitalized elderly. Most of the other studies on polypharmacy used 5 medications as cut-off point for polypharmacy. Since elderly are the largest Vol.33, No.1, July 2021 consumers of medications, we chose a higher cutoff point for this study. In this study exposure to polypharmacy was analyzed based on the number of medications prescribed which is not adequate to determine the appropriateness.

\section{Conclusion}

Substantial proportion of hospitalized elderly were exposed to polypharmacy and received more medications on discharge than admission which may increase the risk of adverse events in elderly patients. There was a tendancy to prescribe lipidmodifying and antithrombotic agents to elderly patients. Medication reconciliation on admission and discharge regular medication review at follow up need to be facilitated to reduce the exposure to polypharmacy which in turn reduce the medicationrelated harm in elderly. However, polypaharmacy is not always inappropriate. Further studies covering larger and diverse population are needed to explore the appropriateness of polypharmacy in elderly patients.

\section{Acknowledgment}

The authors thank the data collectors Dr. Jasiththa Ramachandran and Dr. Verni Gunarajasingam, Senior Techinical Officer Mr. Subramaniam Thayaparan for helping in data processing and the physicians and staff of medical wards of Teaching Hospital-Jaffna for the support during data collection.

\section{Conflict of interest}

The authors have no direct or indirect conflicts of interest.

\section{References}

1. Seminar on the social, health and economic consequences of population aging in the context of changing families; 2007 July 2527, Bangkok. United Nations Economic and -20 - 
Social Commission for Asia and Pacific, United Nations Population Fund and United Nations Department of economic and Social Affairs, 2007 [cited 2021 Apr 7]. Available from: https://www.un.org/esa/socdev/family/ docs/reportseminar07.pdf

2. Census of Population and Housing 2012. Colombo. Department of Census and Statistics Ministry of Finance and Planning, 2012 [cited 2021 Feb 28]. Available from: http://www. statistics.gov.1k/PopHouSat/CPH2011/Pages/ Activities/Reports/CPH_2012_5Per_Rpt.pdf

3. Hilmera SN, McLachlanb AJ, Le Couteur DG. Clinical pharmacology in the geriatric patient. Fundam Clin Pharmacol.2007 Jun;21(3):21730 .

4. Gallagher P, O’Mahony D. Inappropriate prescribing in older people. Reviews in Clinical Gerontology. 2008 Feb 1;18(1): 77-90.

5. Gurwitz JH. Polypharmacy: A New paradigm for quality drug therapy in the elderly? Editorial. Arch Intern Med. 2004 Oct 11; 164(18):1957-1959.

6. Pitkala KH, Strandberg, TE, Tilvis RS. Is it possible to reduce polypharmacy in the elderly? A randomised, controlled trial. Drugs \& Aging. 2001;18(2):143-9.

7. Anthierens S, Tansens A, PetrovicM,Christiaens T. Qualitative insights into general practitioners views on polypharmacy. BMC Fam Pract. 2010 Sep 15 [cited 2021 Apr 7];11:65. Available from: https://bmcfampract.biomedcentral. com/articles/10.1186/1471-2296-11-65. doi:10.1186/1471-2296-11-65

8. Masoodi NA. Polypharmacy: To Err is Human, To Correct Divine. BJMP. 2008 Sep;1(1): 6-9.
9. Bushardt RL, Massey EB, Simpson TW, Ariail JC, Simpson KN. Polypharmacy: Misleading, but manageable. Clin Interv Aging. 2008 Jun; 3(2): 383-389.

10. Jyrkkä J, Enlund H, Korhonen MJ, Sulkava R, Hartikainen S. Patterns of drug use and factors associated with polypharmacy and excessive polypharmacy in elderly persons: results of the Kuopio 75+ study: a cross-sectional analysis. Drugs \& Aging. 2009 Jun;26(6):493-503.

11. Slabaugh SL, Maio V, Templin M, Abouzaid S. Prevalence and Risk of Polypharmacy among the Elderly in an Outpatient Setting: A Retrospective Cohort Study in the EmiliaRomagna Region, Italy. Drugs \& Aging. 2010 Dec;27 (12):1019-1028.

12. Hughes SG. Prescribing for the elderly patient: why do we need to exercise caution? Br JClin Pharmacol. 1998 Dec;46(6):531-3.

13. Klotz U. Pharmacokinetics and drug metabolism in the elderly. Drug Metab Rev. 2009;41(2):67-76.

14. Schwartz JB, Abernethy DR. Aging and Medications: Past, Present, Future: Clin Pharmacol Ther. 2009 Jan; 85(1):3-10.

15. Guidelines for ATC classification and DDD assignment $2012.15^{\text {th }}$ ed. Oslo, Norway: WHO Collaborating Centre for Drug Statistics Methodology; 2011.

16. Nobili A, Garattini S, Mannucci PM. Multiple diseases and polypharmacy in the elderly: challenges for the internist of the third millennium. Journal of Comorbidity. 2011 Dec $27 ; 1: 28-44$.

17. Castelino RL, Sarah N Hilmer SN, Bajorek BV, Nishtala P, Chen TF. Drug Burden Index and potentially inappropriate medications in 
community-dwelling older people: the impact of Home Medicines Review. Drugs \& Aging. 2010 Feb ;27(2):135-48.

18. Peter $\mathrm{N}$ et al. A critical review of admission and discharge medications in an elderly Australian population. Drugs \& Aging, 1993; 3 (4): 358362.

19. Corsonello A, Pedone C, Corica F, Incalzi RA. Polypharmacy in elderly patients at discharge from the acute care hospital. Therapeutics and Clinical Risk Management. 2007: 3(1) 197-203.

20. Chan DC, Hao YT, Wu SC. Polypharmacy among disabled Taiwanese elderly: a longitudinal observational study. Drugs \& Aging. 2009 Apr;26(4):345-54.

21. Junius-WalkerU, GTheile, EHummers-Pradier. Prevalence and predictors of polypharmacy among older primary care patients in Germany. Fam Pract. 2007 Feb;24(1):14-9.

22. Hajjar ER, Cafiero AC, Hanlon JT. Polypharmacy in elderly patients. Am J Geriatr Pharmacotherapy. 2007 Dec;5(4):345-51.
23. Annual health statistics 2017, Sri Lanka, Colombo Medical Statistics Unit Ministry of Health, Nutrition and Indigenous Medicine, 2019 [cited 2021 Feb 28]. Available from: http://www.health.gov.lk/moh_final/english/ public/elfinder/files/publications/AHB/2017/ AHS2017.pdf

24. Senaratne R, Mendis S. Prevention and Control of Noncommunicable Diseases Think Globally-Act Locally; Lessons from Sri Lanka. Ministry of Health, Nutrition and Indigenous Medicine, Sri Lanka, 2018 [cited 2021 Feb 28].Available from: http://www.health.gov. lk/moh_final/english/public/elfinder/files/ Downloade/NCDbook2018.pdf

25. Rieckert A, Trampisch US, Klaaßen-Mielke R, Drewelow E, Esmail A, Johansson T, et al. Polypharmacy in older patients with chronic diseases: a cross-sectional analysis of factors associated with excessive polypharmacy. BMC Family Practice. 2018 July 18[cited 2021 Apr2];19:113. Available from: https://bmcfampract.biomedcentral.com/ articles/10.1186/s12875-018-0795-5. doi: 10.1186/s12875-018-0795-5. 